\title{
Financial Autonomy of Territorial Communities and the Attractiveness of Moroccan Regions
}

\author{
Sophia BEKKAOUI ${ }^{1}$ and Mohammed EL GAZI ${ }^{2}$ \\ ${ }^{1-2}$ Doctor in Economics and management \\ ${ }^{1-2}$ Faculty of Economical and Social Legal Sciences \\ First Mohammed University. OUJDA
}

Morocco

\begin{abstract}
Morocco is engaged in a major project that advanced regionalization, whose objective is to erect the twelve regions as poles of competitiveness to even boost national economic growth. This cannot be done without a genuine financial autonomy of those regions. However, we find that the territorial communities do not enjoy real financial autonomy (Tax Centralized, which redistributes the revenue according to the principle of solidarity between the regions). This lack of financial autonomy would constitute a serious handicap to the attractiveness territorial regions.

The objective of this article is to analyze the situation of local finances in Morocco through a reading of the organic laws relating to territorial communities. As well, we highlight the inadequacy of these laws in order to strengthen the financial autonomy of the communities and therefore the financial power of the elected Committee.
\end{abstract}

Keywords: Territorial Communities, Financial Autonomy, Free Administration, Territorial Attractiveness, Advanced Regionalization.

\section{INTRODUCTION}

No one can dispute that the paramount objective for local public action is to promote a sustainable local development on the whole of the territory. Such is the credo of the advanced regionalization. This last is a prelude to a profound reform of the public governance, through a process of decentralization.

The regionalization is positioning the territorial actors at the heart of public action. It part of the principle according to which local elected representatives are the best placed to discuss the needs, aspirations and local projects. As well they will have to be, to even define their strategy, to plan and implement the actions relating thereto by drawing on the resources and potentials of their own territories to engage the dynamics of specific development integrated in a democratic framework which defines the responsibilities.

In this context, the financial autonomy is the principal issue of the attractiveness of the territories as well as of their developments. This brings us to return to the fundamental theories having focused on the modern State, including the relations between the Center and the periphery.

Where the object of this article is to study the degree of financial autonomy of territorial communities through a reading of the organic law relating to territorial communities ' $T C$ ' developed as a result of the constitutional revision of 2011.

\section{THE FINANCIAL AUTONOMY OF TERRITORIAL COMMUNITIES, A MAJOR ISSUE OF THE TERRITORIAL ATTRACTIVENESS}

The attractiveness of the territories are measure, in our sense, through the ability of a given space to offer good conditions of life to its inhabitants and to create wealth. Therefore, the two major dimensions of the attractiveness of the territories, are, the quality of life for the citizen and economic competitiveness for the company, otherwise say the business climate. The latter is an index which measures the ability of the regions, for a given period, to attract all kinds of economic activities and other factors of production mobile (enterprises, professional events, entrepreneurs, capital, Foreign Direct Investment 'FDI'...).

The business climate covers 9 important dimensions, namely: institutions and governance, infrastructure and urbanization, health, education and skills, adoption of information technology, financial inclusion, labor market, dynamism of business and innovation. 


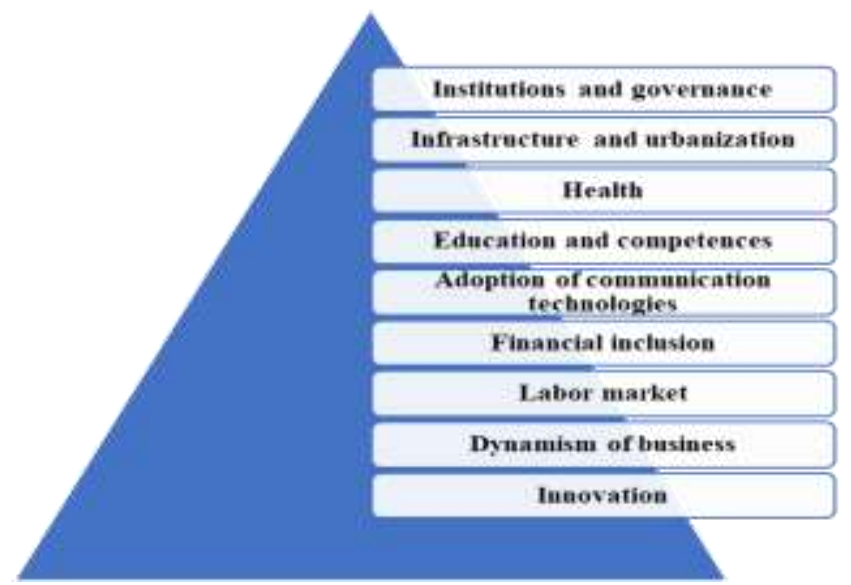

Figure 1. The dimensions of the business climate according to Doing Business Report [1]

As we see the governance constitutes the first index to take into consideration to assign an index of attractiveness, and which is in our view, the most important of the time that explains the other indices.

Of this fact, a good local governance requires that the State is developing a mechanism for the transfer of jurisdiction in areas defined (principle of free administration), with as a corollary the recognition of a financial autonomy to ensure a good business climate.

\subsection{Principle of free administration}

The Moroccan Constitution revision of 2011 has confirmed the principle of free administration of the territorial communities. The Article 136 sets out henceforth as well this principle: "The organization regional and territorial level is based on the principles of free administration, cooperation and solidarity". Therefore the principle of free administration, principle of constitutional rank, is required in the legislature and all administrative authorities in particular :

$\checkmark$ Have an elected Council, with actual assignments and a reglementary power

$\checkmark$ Have the financial autonomy

$\checkmark \quad$ Create and delete emplois, recruit and manage its staff

$\checkmark$ Conclude contracts

$\checkmark$ Set their own internal operating rules by means of their interior reglement.

\subsection{Principle of the financial autonomy of the territorial communities}

The Moroccan Constitution defines the elements of the financial autonomy, in the form of principles.

\subsubsection{The foundations of the financial autonomy}

The financial autonomy makes effective the legal autonomy which is ensured by the legal personality that is recognized to territorial communities. This last is only an illusion if the elected body does not have a power of decision with respect to the evolution of its revenue and expenditure. The financial autonomy implies the presence of three indices [2]. First, the existence of a freedom for the implementation of public policy, then a power of decision to spend public funds and finally the freedom to act on the local taxation system. Therefore, it is at once a management autonomy and a fiscal autonomy.

However, these indices remain rather theoretical because they do not allow to account for the complex reality of the financial regime applicable to territorial communities.

\subsubsection{The financial autonomy in the Moroccan Constitution}

The concept of financial autonomy is not defined by any article of the Constitution and the only basis remains the principle of free administration in Article 136 (the territorial organization of the kingdom is based on the principles of free administration, cooperation and solidarity). This same article guarantees the participation of the population in the management of their affairs and the creation of a favorable environment for their contributions to the integrated human development sustainable. This participation should be ensured by the mechanisms of dialog put in place by the advice of the regions and the advice of the territorial communities [3]. Also, the article 140 of the Constitution puts forward the principle of subsidiarity (on the basis of the principle of subsidiarity, the territorial communities have of own competences, skills shared with the State and those which their are transferable by the latter.

In addition to own financial resources available to the territorial communities, the Constitution imposes the obligation to accompany any transfer of powers to the regions and other territorial communities of a transfer of the corresponding resources [4]. Under the constitutional depositions mentioned, one could estimate that the implementation of the principle of free administration assumed a power of decision exercises by the elected Council and a sufficient level of resources. Knowing that the financial power of the territorial communities has always been limitations because of their dependence of transfers and state grants. 
However, the article 71 of the Constitution strictly limits the financial power of the territorial communities, of which the definition return to the the legislative power. The same article 39 of the Constitution away any possibility of having a tax freedom for the legislative advice (all support in proportion to their contributory, public charges that only the law can, in the forms provided for by the present Constitution, create and share). Only the legislator is therefore comptent to fix, in accordance with the article 41 of the Constitution, the rules concerning the base, the Rates and terms and conditions for the recovery of all local taxation.

The constitutional dispositions have been clarified by the organic laws relating to territorial communities promulgated in July 2015 and which evoke the principle of financial autonomy without the explain [5].

The review of legal dispositions also reveals that the territorial communities enjoy a relative budgetary autonomy. In addition, their financial autonomy is hampered by other factors.

\section{THE REALITY OF LOCAL FINANCES: THE PREPONDERANCE OF STATE TRANSFERS}

The consecration of the financial autonomy is therefore far from being acquired in Morocco. In the Analyzing the characteristics of fiscal resources, one realizes that the share of local taxation in the financing of local budgets seems to constitute an obstacle to the strengthening of the financial autonomy of territorial communities.

Even if communities have of own resources in progression, the State transfers remain very important. These transfers are essentially constituted by the assignment of a share of the proceeds of the Tax on the value added 'TVA' which exceed the tax resources own of the territorial communities.

\subsection{The fiscal resources own territorial communities}

The fiscal resources own territorial communities can be classified in two categories, the resources directly managed by the Communities and the resources managed by the State for the benefit of the communities.

\subsubsection{The resources managed by the territorial communities}

The fiscal resources are managed by the territorial communities remain low property that they know a dynamic evolution since the reform of local taxation in 2008. Their share in the total resources is 20 per cent in 2017 [6].

These resources are constituted in large part by tax on urban land not built, the frontier revenues, the tax on the operations of the construction, the royalty communal Temporary Occupation of the public Domain 'TOPD' and the royalty on the revenue of agents of the wholesale markets. These resources have reached 7.1 MMDH.

\subsubsection{The resources managed by the State for the benefit of the territorial communities}

These resources are increased from 5.4 MMDH in 2015 has 5,75MMDH has end of 2017. Their structure is based, in the first place, on the tax on the communal services and also on the tax professional. The housing tax, for it tends to become a resource in the second row. The share of resources managed for the account of the Communities rises to $17.22 \%$ of total revenues.

\subsection{The State transfers for the benefit of the territorial communities}

The State transfers are carried out on the basis of a mechanism in equalization to reduce inequalities between communities and ensure them a minimum of resources. These transfers were represented on average $61.9 \%$ of their revenue. These tax revenues consist of transfers of $30 \%$ under the TVA, transfers of $1 \%$ of the recipe of the Tax on the Company and the Incom Tax [7].

In the knowledge that the recipe of the territorial communities are formed for $76.5 \%$ of their share in the product of the TVA.

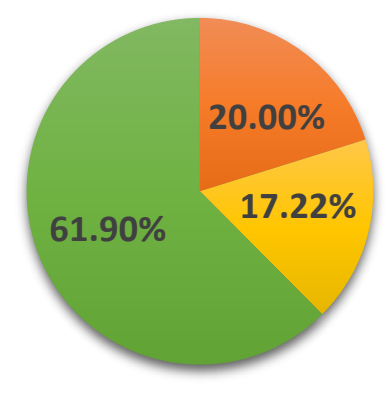

The resources administered by the CT. The resources administered by the State

The resources transferred

Figure 2. Structure of the resources of the TC [6]

We noting that there is a predominance of resources transferred or manage by the State which represents on average $79 \%$, which explains the strong dependence of the territorial communities opposite the State and constitutes a significant indicator of the limits of the tax autonomy. 


\section{LIMITS OF FHE FINANCIAL AUTONOMY IN THE LIGHT OF THE ORGANIC LAW RELATING TO TERRITORIAL COMMUNITIES}

The constitutional principle of free administration and the business climate local, constitute the pillars of an attractive territory require a financial autonomy of the territorial communities. This autonomy should allow their including the availability of resources commensurate with the responsibilities provided for by the texts and the freedom to use their resources. They must also take advantage of a financial equalization intended to correct the unequal distribution of funding resources and expenses.

We will find in the light of the organic laws relating to local communities that the consecration of the financial autonomy faces limits which affect the expenditure as resources.

\subsection{Limits to the level of expenditure}

The indices are essential to ensure the financial autonomy of territorial communities are taken into consideration. The determination of the nature, amount and the functional distribution of expenditure is not exclusively of communities but stems in varying proportions of the State.

First of all, the nature of the expenditure depends on the sharing of powers between the State and the territorial communities and conducts as well the Act.

Also, the territorial communities must ensure compulsory expenditure which restrict their freedom of choice. However, all the compulsory expenditure, as well qualified by the budgetary control, do not contribute to improve the benefits in terms of local development. Indeed, most of the expenditure mentioned correspond to the recurrent operating costs.

\subsection{The limits to the level of resources}

In relation to the resources, the financial autonomy of the territorial communities also faces the limits. Indeed, the definition of fiscal resources, the fixing of the rates and amounts do not arise from the power of communities but depend first of all of the depositions of the Act as specific articles 39 and 71 of the Constitution.

As example, the organic law concerning the regions lists the resources intended for the financing of the region. The latter benefits from the following resources:

$\checkmark$ The product taxs authorized in the framework of law of finance

$\checkmark$ The financial allocations of the general budget of the State

$\checkmark \quad$ The product of the royalties imposed under the legislation in force

$\checkmark$ The product of the remuneration for services rendered under the organic law

$\checkmark \quad$ The product of the almonds under the legislation in force

$\checkmark$ The product of farms, royalties, equity participations

$\checkmark$ Grant of the state

$\checkmark \quad$ The product of the authorized borrowing

$\checkmark$ The property income

$\checkmark$ Donations.

In addition, are created in the application of the article 142 of the Constitution two funds, namely the fund to upgrade to the social level who is intended to compensate for the deficits in the areas of human development, basic infrastructure and equipment and the interregional solidarity fund which aims the equitable distribution of resources in order to reduce the disparities between regions.

But, it is important to point out that the funding of these funds remains uncertain since it depends on the economic activity and the situation of public finances.

\section{CONCLUSION}

In conclusion, the review of the situation in Morocco reveals that the Constitution has enshrined the general principle of free administration of territorial communities without the surround of sufficient guarantees through the explicit affirmation of a financial autonomy, of even the organic law of 2015 evoke a form of financial autonomy without proceed to its definition. This silence limits its effective exercise.

As well the reading of the laws relating to territorial communities, it is possible to say that this autonomy is only relative. On the one hand the power of decision in respect of financial matters is very limited and the control that is exercised on their decisions remains narrow. On the other hand, they have neither the financial resources nor the mastery of their financial burden. To this title, the report of force is characterized by a form of subordination of the communities has the State the fact of these limits of their financial autonomy. Thus constituting a limitation of the decision-making authority of elected councils including tax, which negatively impacts the business climate of the regions and therefore their attractivités.

A consolidation of the financial autonomy of the territorial communities is therefore necessary. It must incorporate two dimensions. The first is that of the consecration of the financial autonomy real. The one linked to the amount, in absolute value, the own resources of the territorial communities and in particular the tax resources. The second is to strengthen the financial power of deliberative assemblies in tax matters, including the possibility of changing and vote the rates of local taxs. 
International Journal of Advances in Scientific Research and Engineering (ijasre), Vol 5 (9), September-2019

\section{BIBLIOGRAPHIC REFERENCES :}

1. World Bank Group Report, Doing Business: Training for reform, 2019, 16th Edition, p.29.

2. Éric portal, foreword, < the financial autonomy of the CL in Europe> RFFP, N 121, February 2013, pp : 3...6.

3. Art 139 of the Moroccan Constitution.

4. Art 141 of the Moroccan Constitution.

5. Art 2 and 3 of the organic laws $111.14,112.14$ and 113.14 relating to territorial communities.

6. General Treasury of the Kingdom, Morocco, BULLTIN of local finance, November 2017.

7. Framework legislation on tax reform, 1985. 